Available online at http://journal.stkip-andi-matappa.ac.id/index.php/histogram/

Histogram : Jurnal Pendidikan Matematika ., 2019, 141 - 151

\title{
PENERAPAN SOFTWARE GEOGEBRA PADA PEMBELAJARAN TOPIK LINGKARAN DALAM MENINGKATKAN HASIL BELAJAR SISWA
}

\author{
Desyarti Safarini TLS ${ }^{1 *}$, Faqih Al Adyan ${ }^{2}$ \\ ${ }^{1}$ Sampoerna University, ${ }^{2}$ Bunda Mulia School \\ * Corresponding Author. Email: desyarti.safarini@sampoernauniversity.ac.id \\ Received: 01 Agustus 2019; Revised: 18 Agustus 2019 ; Accepted: 30 September 2019
}

\begin{abstract}
ABSTRAK
Matematika merupakan salah satu bidang ilmu yang dianggap sulit oleh kebanyakan siswa, sehingga tidak sedikit siswa yang memperoleh hasil belajar matematika yang rendah. Penggunaan media pembelajaran dapat membantu siswa dalam memahami konsep matematika yang pada akhirnya dapat meningkatkan hasil belajarnya. Penelitian ini mengkaji mengenai penerapan media software GeoGebra pada pembelajaran topik lingkaran di suatu Sekolah Menengah Pertama (SMP) di Jakarta dan mendeskripsikan tentang bagaimana hasil belajar siswa dapat meningkat melalui pembelajaran tersebut. Penelitian ini berjenis kualitatif deskriptif dengan teknik analisa data model Miles dan Huberman dan melalui proses triangulasi data. Hasil penelitian ini menunjukkan bahwa penerapan media software GeoGebra dapat membantu siswa dalam memahami materi pada topik lingkaran, sehingga hasil belajar siswa meningkat sebesar 30\%.
\end{abstract}

Kata Kunci: software GeoGebra, lingkaran, hasil belajar

How to Cite: Safarini, D,. Adyan, F, A. (2019). Penerapan Software Geogebra pada Pembelajaran Topik Lingkaran dalam Meningkatkan Hasil Belajar Siswa. Histogram: Jurnal Pendidikan Matematika, 3(2), 141 - 151, doi: http://dx.doi.org/10.31100/histogram.v3i2.466

Permalink/DOI: http://dx.doi.org/10.31100/histogram.v3i2.466

\section{PENDAHULUAN}

Matematika merupakan salah satu bidang ilmu yang berperan penting dalam kehidupan manusia. Lindquist (2009) menjelaskan bahwa matematika dapat dijadikan strategi dalam mengolah, menganalisis dan mensintesis suatu informasi. Beberapa masalah di kehidupan sehari-hari dapat dibuat model matematikanya untuk dapat diperoleh solusinya dengan lebih mudah. Namun, kontras dengan pentingnya peranan matematika tersebut, mayoritas siswa kurang menyukai matematika dan mengalami kesulitan dalam 


\section{Histogram: Jurnal Pendidikan Matematika, 3 (2), 2019 - 142 \\ Desyarti Safarini TLS ${ }^{1^{*}}$, Faqih Al Adyan ${ }^{2}$}

memahaminya. Brueckner dan Bond, Cooney, Davis, dan Henderson (dalam Widdiharto, Anggraeni, \& Guntoro, 2008) menyatakan bahwa beberapa contoh kesulitan belajar matematika yang sering terjadi pada siswa adalah sulit berpikir abstrak, deduktif, dan memahami konsep dasar. Kesulitan dalam belajar matematika dapat menyebabkan rendahnya hasil belajar siswa.

Kesulitan belajar Matematika juga dialami oleh siswa kelas VIII di salah satu SMP di Jakarta, sehingga hasil belajarnya rendah. Data hasil belajar siswa berdasarkan hasil tes pada sub topik mengenai konsep dasar lingkaran, serta juring dan tembereng lingkaran, diketahui hanya mencapai rata- rata nilai sebesar 43. Sebanyak $82.14 \%$ siswa di kelas tersebut mendapatkan nilai di bawah Standar Ketuntasan Belajar Minimal (SKBM), yaitu kurang dari 60. Hal ini menunjukkan bahwa hasil belajar siswa tergolong rendah dan perlu dilakukan perbaikan proses pembelajaran yang dapat mengatasi kesulitan belajar siswa, sehingga hasil belajarnya dapat meningkat dan mencapai target minimal yang diharapkan.

Penerapan media pembelajaran dapat membantu siswa untuk mengatasi kesulitannya dalam memahami konsep matematika. Beardon \& Way (2003) menyatakan bahwa penerapan media teknologi dapat mendukung proses pembelajaran di kelas. Souter (t.th) dalam penelitiannya juga menyatakan bahwa siswa di kelas yang menerapkan media teknologi memperoleh hasil belajar yang lebih tinggi dibanding siswa yang belajar di kelas konvensional. Penggunaan media teknologi seperti software pembelajaran dapat memberikan kesempatan yang lebih besar bagi siswa untuk melakukan abstraksi, manipulasi, dan eksplorasi terhadap berbagai konsep matematika. Machin dan Rivero (2002) dalam penelitiannya juga menyimpulkan bahwa pembelajaran dengan teknologi membantu siswa membangun rasa percaya diri dan motivasi dalam belajar matematika, serta memberikan kesempatan siswa untuk lebih aktif terlibat dalam proses belajar.

Lebih lanjut, NCTM (2000) menyatakan bahwa teknologi seperti software merupakan salah satu sarana penting dalam pembelajaran matematika yang berperan dalam memvisualisasikan berbagai konsep matematika, mengolah data statistik, serta melakukan perhitungan secara tepat dan akurat. Salah satu media software yang dapat digunakan dalam mendukung pembelajaran matematika adalah software Geogebra. Dokovic (2009) menyatakan bahwa Geogebra merupakan software gratis yang memiliki beragam fitur yang memungkinkan guru dan siswa untuk memasukkan persamaan, membuat grafik, bahkan mencari turunan dan integral. Software Geogebra juga digunakan sebagai media bagi siswa dan guru dalam mengeksplorasi beragam konsep matematika. Geogebra dapat membantu siswa melakukan beragam eksplorasi, memahami, dan kemudian 


\section{Histogram: Jurnal Pendidikan Matematika, 3 (2), 2019 - 143 \\ Desyarti Safarini TLS ${ }^{*}$, Faqih Al Adyan ${ }^{2}$}

memvisualisasikan berbagai konsep dasar matematika secara lebih dalam (Embacher dkk., 2006 dalam Freiman, Martinovic \& Karadag, 2010).

Dengan mempertimbangkan peran penting media software dalam pembelajaran Matematika, peneliti ingin mengkaji penerapan media software Geogebra khususnya pada sub topik sudut pusat dan sudut keliling. Diharapkan penerapan media software Geogebra dalam pembelajaan di kelas dapat membantu siswa mengatasi kesulitan belajarnya, sehingga pada akhirnya siswa memperoleh hasil belajar yang lebih tinggi. Berdasarkan hasil observasi awal diketahui bahwa sekolah yang bersangkutan telah didukung oleh berbagai sarana prasarana yang diperlukan dalam menerapkan media software Geogebra pada pembelajaran matematika. Selain itu, peneliti juga mendapati fakta bahwa mayoritas siswa sudah terbiasa dalam menggunakan teknologi dalam kehidupan sehari-hari. Berdasarkan hasil pengamatan awal tersebut, penelitian ini menjadi relevan dan penting untuk dilakukan.

Tujuan penelitian ini adalah mengkaji penerapan software Geogebra pada pembelajaran topik sudut pusat dan sudut keliling dalam meningkatkan hasil belajar siswa. Hasil belajar yang dimaksud dibatasi pada aspek kognitif yang diukur berdasarkan hasil tes tertulis, seperti post test atau ulangan harian. Untuk mencapai tujuan tersebut, peneliti memiliki beberapa pertanyaan penelitian, yaitu:

1. Apakah penerapan media software Geogebra pada pembelajaran topik sudut pusat dan sudut keliling dapat meningkatkan hasil belajar siswa?

2. Jika ya, bagaimana hasil belajar siswa dapat meningkat melalui penerapan media software Geogebra?

\section{METODE PENELITIAN}

Jenis penelitian ini menggunakan pendekatan kualitatif. Metode yang digunakan dalam penelitian ini adalah deskriptif yang untuk mengekplorasi dan menggambarkan keadaan lapangan yang akan diteliti secara menyeluruh, luas, dan mendalam (Sugiyono, 2013). Pada penelitian ini, peneliti berupaya memperoleh gambaran yang jelas mengenai bagaimana hasil belajar siswa dapat meningkat melalui penerapan software Geogebra dalam pembelajaran topik sudut pusat dan sudut keliling. Penelitian dilaksanakan di salah satu kelas VIII di sebuah Sekolah Menengah Pertama (SMP) swasta di Jakarta dengan jumlah siswa di kelas sebanyak 28 orang. Validasi data pada penelitian ini menggunakan sistem triangulasi di mana peneliti memanfaatkan berbagai sumber dan perspektif dalam mengolah data. 


\section{Histogram: Jurnal Pendidikan Matematika, 3 (2), 2019 - 144 \\ Desyarti Safarini TLS ${ }^{1^{*}}$, Faqih Al Adyan ${ }^{2}$}

Pengumpulan data pada penelitian ini dilakukan melalui observasi, wawancara, penyebaran kuosioner, dan pemberian tes. Pada penelitian ini, subjek penelitian dipilih melalui teknik purposive sampling, yaitu sesuai dengan karakteristik dan tujuan penelitian. Subjek penelitian (SP) dipilih berdasarkan kemampuan akademiknya, yaitu terdiri dari 2 orang siswa dari kategori kemampuan akademik tinggi, 2 orang dari kategori kemampuan akademik menengah, dan 2 orang dari kategori kemampuan akademik rendah. Seluruh SP diwawancarai di akhir pembelajaran untuk memperoleh data yang lebih mendalam tentang persepsi siswa terhadap penggunaan media software Geogebra pada pembelajaran topik lingkaran. Analisis data dilakukan dengan mengadopsi model Miles dan Huberman yang terdiri dari tiga tahap, yaitu reduksi data, penyajian data, dan penarikan kesimpulan.

\section{HASIL DAN PEMBAHASAN}

\section{A. Hasil Penelitian}

Penerapan software Geogebra pada pembelajaran topik sudut pusat dan sudut keliling dilaksanakan melalui kegiatan diskusi kelompok. Penggunaan software ini digunakan dalam pembelajaran terkait materi sudut pusat dan sudut keliling, segi empat tali busur dan sudut yang dibentuk oleh 2 tali busur di dalam dan di luar lingkaran. GeoGebra memiliki kelebihan yang dapat mendukung simulasi dan visualisasi gambar lingkaran beserta elemen-elemennya serta letak-letak sudut pada lingkaran. Salah satu contoh penerapan software GeoGebra dalam mempelajari topik lingkaran dapat dilihat pada Gambar 1. 
Histogram: Jurnal Pendidikan Matematika, 3 (2), 2019 - 145

Desyarti Safarini TLS ${ }^{*}$, Faqih Al Adyan ${ }^{2}$
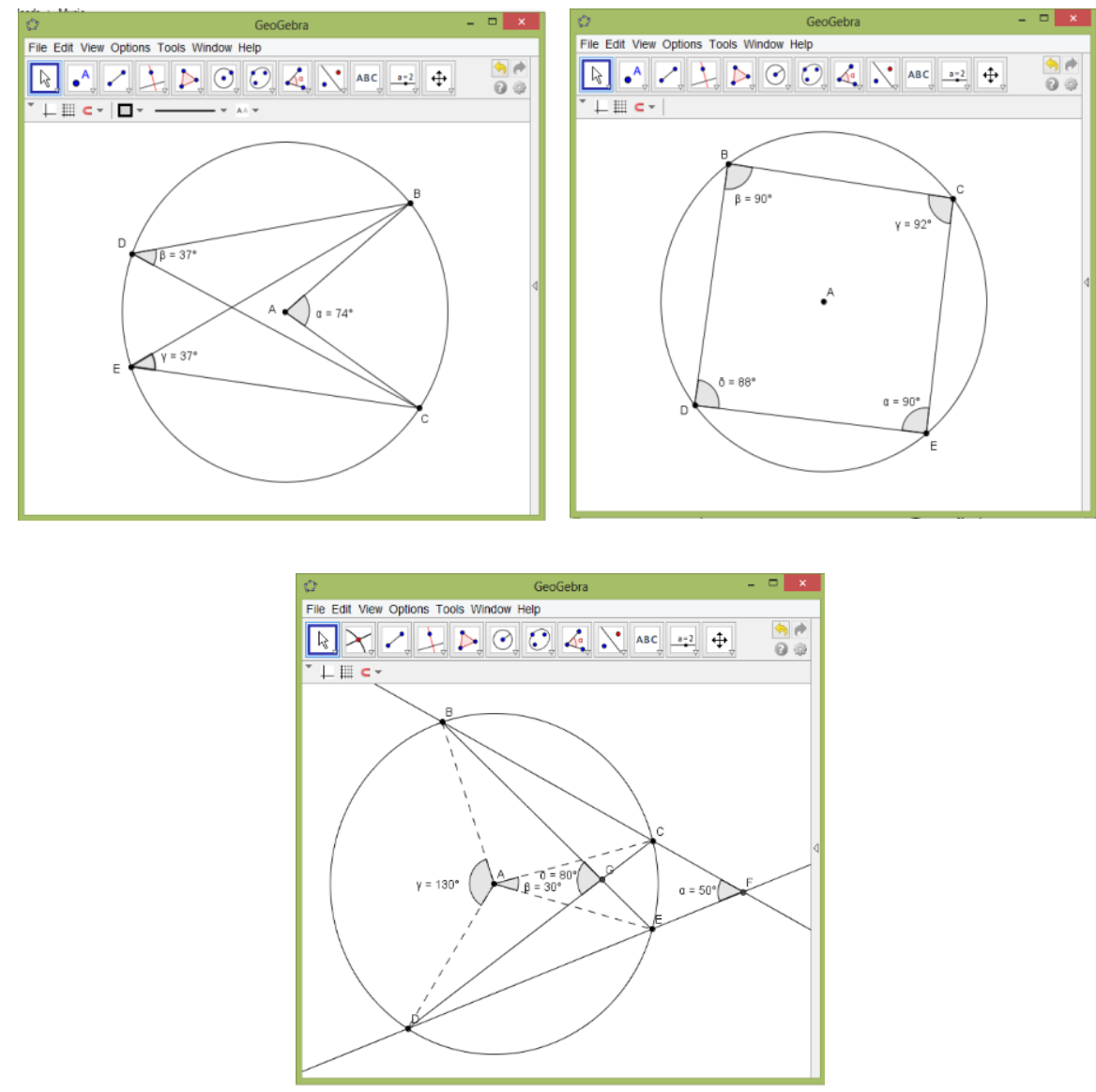

Gambar 1. Penggunaan software geogebra pada topik sudut pusat dan sudut keliling

Pada saat pembelajaran, software GeoGebra digunakan sebagai alat bantu bagi guru dalam menjelaskan materi, yaitu melalui simulasi dan visualisasi konsep, sedangkan software GeoGebra bagi siswa digunakan sebagai alat bantu untuk melakukan eksplorasi konsep matematika dan menyelesaikan beragam soal-soal baik pada saat mengerjakan latihan maupun tugas. Selama penelitian, pembelajaran dilaksanakan di laboratoium komputer untuk memaksimalkan penggunaan software Geogebra.

Untuk mendukung kegiatan eksplorasi, dibentuk kelompok heterogen agar terjadi diskusi antarsiswa baik saat mengerjakan soal latihan maupun tugas dengan menggunakan media software Geogebra. Tugas kelompok wajib diselesaikan oleh siswa baik dengan menggunakan media software GeoGebra maupun secara analitik. Tujuan pemberian tugas kelompok tersebut untuk meningkatkan aktivitas eksplorasi terhadap konsep lingkaran dengan menggunakan media software Geogebra yang pada akhirnya diharapkan dapat meningkatkan pemahaman konsep. Dengan demikian siswa mampu menyelesaikan beragam soal secara analitik dan pada akhirnya hasil belajar siswa dapat meningkat. Di 
akhir sesi pembelajaran pada pertemuan keempat, peneliti memberikan tes akhir untuk mengukur hasil belajar siswa melalui penerapan media software Geogebra. Hasil belajar siswa dapat dilihat pada Gambar 2.

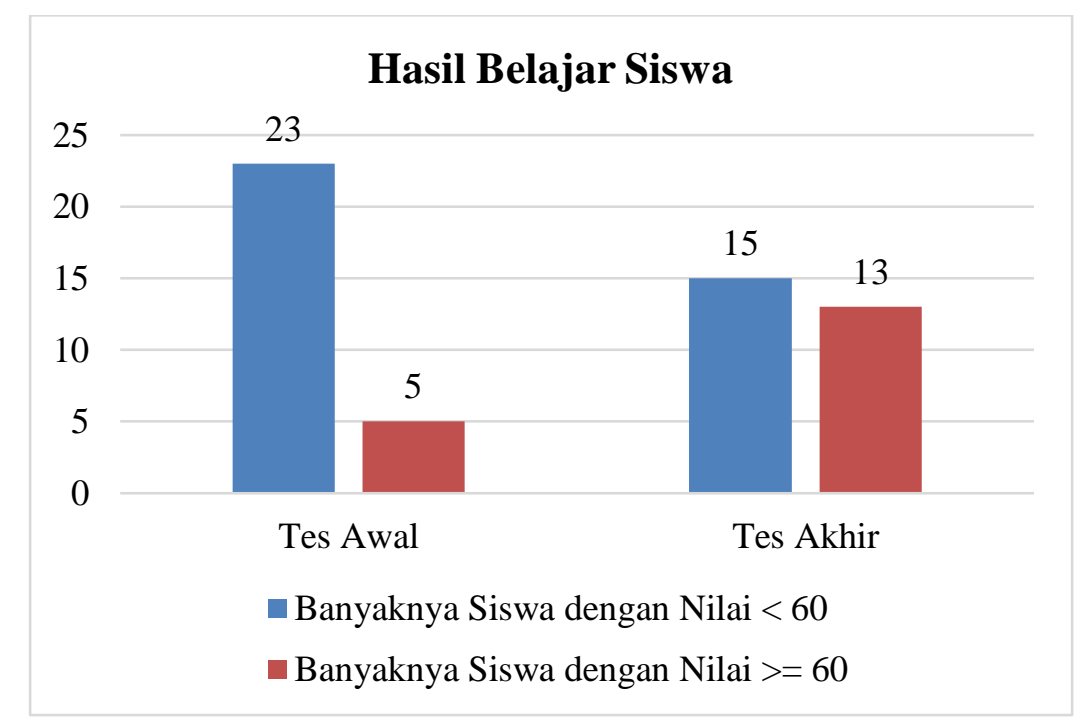

Gambar 2. Hasil belajar siswa

Rata-rata nilai yang diperoleh siswa adalah 58,78 dengan nilai tertinggi 100 dan nilai terendah 14. Rata-rata nilai dari tes awal ke tes akhir meningkat, yaitu sebesar $30 \%$. Persentase siswa yang mendapatkan nilai lebih dari SKBM juga meningkat dari sebelumnya hanya $17.86 \%$ (5 orang siswa) menjadi $46.43 \%$ (13 orang siswa). Sebaliknya, persentase siswa dengan nilai kurang dari SKBM menurun dari sebelumnya sebesar 82.14\% (23 orang siswa) menjadi 53.57\% (15 orang siswa). Sedangkan hasil belajar seluruh SP dapat dilihat representasinya pada Gambar 3. 


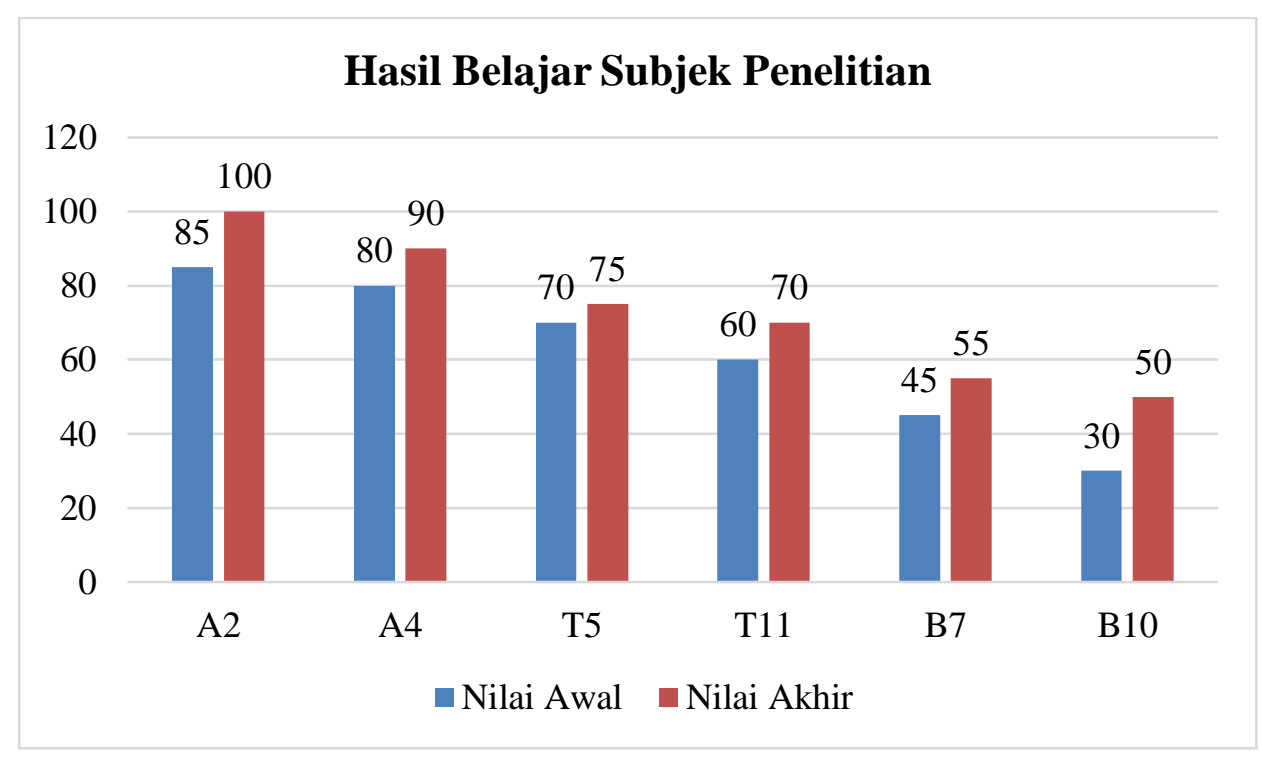

Gambar 3. Hasil belajar subjek penelitian

Seluruh SP memperoleh peningkatan hasil belajar dengan rata-rata peningkatan sebesar 23,80758\%. Nilai tertinggi yang dicapai oleh SP adalah 100 oleh A2 dan nilai terendah sebesar 50 oleh B10. Dari keenam SP terdapat 2 orang SP yang masih memiliki nilai kurang dari SKBM. Akan tetapi kedua SP tersebut memperoleh peningkatan hasi belajar, masing-masing sebesar $22,22 \%$ dan $66,67 \%$. Persentase peningkatan tertinggi dicapai oleh B10, yaitu sebesar $66,67 \%$. Sedangkan persentase peningkatan terkecil dicapai oleh T5, yaitu sebesar 7,143\%.

Lebih lanjut, hasil tugas seluruh SP selama pembelajaran juga menunjukkan hasil yang cenderung meningkat. Rincian hasil tugas SP tersebut disajikan pada Tabel 1:

Tabel 1. Hasil Tugas Subjek Penelitian

\begin{tabular}{ccccc}
\hline No. & $\begin{array}{c}\text { Kode } \\
\text { Siswa }\end{array}$ & Tugas 1 & Tugas 2 & Tugas 3 \\
\hline $\mathbf{1}$ & A1 & 70 & 75 & 100 \\
\hline $\mathbf{2}$ & A2 & 80 & 85 & 100 \\
\hline $\mathbf{3}$ & T1 & 60 & 70 & 80 \\
\hline $\mathbf{4}$ & T2 & 65 & 70 & 85 \\
\hline $\mathbf{5}$ & B1 & 60 & 70 & 80 \\
\hline $\mathbf{6}$ & B2 & 60 & 70 & 80 \\
\hline
\end{tabular}

(Sumber: data primer, Tahun: 2019) 


\section{Histogram: Jurnal Pendidikan Matematika, 3 (2), 2019 - 148 \\ Desyarti Safarini TLS ${ }^{1 *}$, Faqih Al Adyan ${ }^{2}$}

Berdasarkan data pada Tabel 1, diketahui bahwa rata-rata peningkatan nilai tugas seluruh SP berturut- turut adalah $11,85 \%$ dari nilai tugas 1 ke nilai tugas 2, dan 19,21\% dari nilai tugas 2 ke nilai tugas 3. Hasil ini menunjukkan bahwa hasil tugas SP semakin meningkat mulai dari tugas 1 sampai dengan tugas 3. Hal ini dapat dikarenakan SP sudah mulai terbiasa melakukan esplorasi beragam soal dengan menggunakan media software Geogebra, sehingga hasil tugasnya terus meningkat.

Dari hasil kuesioner yang diberikan kepada siswa pada akhir pembelajaran diperoleh hasil sebagaimana ditunjukkan pada Tabel 2 berikut ini.

Tabel 2. Hasil kuesioner siswa

\begin{tabular}{clc}
\hline No. & \multicolumn{1}{c}{ Pernyataan } & $\begin{array}{c}\text { Persentase } \\
\text { Siswa (\%) }\end{array}$ \\
\hline 1. & $\begin{array}{l}\text { Memperhatikan penjelasan guru selama pelajaran } \\
\text { matematika berlangsung. }\end{array}$ & 60 \\
\hline 2. & $\begin{array}{l}\text { Memperhatikan dan mendengarkan penjelasan guru } \\
\text { dengan menggunakan software Geogebra }\end{array}$ & 80 \\
\hline 3. & $\begin{array}{l}\text { software Geogebra membantu belajar matematika } \\
\text { dan memahami materi yang diajarkan guru }\end{array}$ & 80 \\
\hline 4. & Menyukai belajar melalui diskusi kelompok di kelas \\
\hline 6. & Lebih senang belajar dengan anggota kelompok lain & 35 \\
\hline & Bosan belajar dengan menggunakan software & 28 \\
\hline
\end{tabular}

(Sumber: data primer, Tahun: 2019)

Berdasarkan data pada Tabel 2, diketahui bahwa mayoritas siswa (68\%) memberikan perhatian yang lebih terhadap pembelajaran yang disampaikan guru dengan menggunakan media software Geogebra. Siswa juga menyatakan bahwa mereka merasa terbantu dalam memahami materi melalui penggunaan media software Geogebra dalam pembelajaran topik lingkaran. Siswa juga menyukai kegiatan diskusi kelompok baik pada saat mengerjakan soal latihan maupun tugas kelompok. Hanya $28 \%$ siswa yang menyatakan merasa bosan belajar dengan menggunakan media software Geogebra.

Lebih lanjut, hasil wawancara terhadap seluruh subjek penelitian juga menunjukkan hasil yang hampir serupa. Berikut ini adalah cuplikan hasil wawancara dengan beberapa SP terkait pembelajaran topik lingkaran dengan menggunakan media software GeoGebra. 


\section{Histogram: Jurnal Pendidikan Matematika, 3 (2), 2019 - 149 \\ Desyarti Safarini TLS ${ }^{*}$, Faqih Al Adyan ${ }^{2}$}

A2 : "Ya jadi lebih semangat nyelesaiin soal-soal tugas, karena lebih gampang dipahamin jawabannya dan gak susah jalanin softwarenya."

B1 : "Iya, soalnya kita tau asal muasal gambarnya jadi connect sama jawabannya."

T1 : "Iya kebantu soalnya jadi lebih gampang ngertiin gambar sama jawabannya. Saya malah lebih ngerti kalo langsung pakai programnya, bener deh! “

A1 : "Lebih suka belajar kelompok biar bisa sharing jawaban."

B2 : "Lebih suka kelompok supaya bisa nanya-nanya sama temen yang udah ngerti."

Berdasarkan hasil wawancara tersebut, diketahui bahwa subjek penelitian beranggapan penggunaan media software GeoGebra dapat membantu mereka dalam mempelajari topik lingkaran. Mereka merasa lebih mudah dalam memahami konsep, menggambarkan letak sudut dan ukurannya, serta mengerjakan beragam soal pada topik lingkaran. Selain itu, seluruh subjek penelitian juga setuju bahwa kegiatan diskusi kelompok juga membantu mereka dalam menyelesaikan soal-soal latihan dan tugas kelompoknya. Ketika siswa menemukan kesulitan, mereka dapat bertanya dan berdiskusi dengan anggota kelompok yang lain dan pada akhirnya dapat menyelesaikan soal dengan baik. Dengan kata lain, penerapan media software Geogebra yang diintegrasikan dengan kegiatan diskusi kelompok dapat membantu siswa memahami topik lingkaran, sehingga hasil belajar siswa dapat meningkat.

\section{B. Pembahasan}

Penerapan media software Geogebra yang diintegrasikan dengan diskusi kelompok dapat meningkatkan hasil belajar siswa pada pembelajaran topik lingkaran. Hal ini ditunjukkan dari peningkatan nilai tes siswa sebesar 30\%. Hal ini sesuai dengan pernyataan Way dan Beardon (2003) bahwa penggunaan teknologi secara efektif dan efisien dapat meningkatkan hasil belajar dan memenuhi kebutuhan belajar siswa. Lebih lanjut, dari hasil kuesioner siswa juga didapat informasi bahwa $68 \%$ siswa setuju bahwa penggunaan media software Geogebra membantu mereka dalam belajar matematika. Siswa merasa lebih mudah dalam memahami materi yang diajarkan guru dan serta terbantu dalam menyelesaikan soal saat mengerjakan latihan dan tugas kelompoknya. 


\section{Histogram: Jurnal Pendidikan Matematika, 3 (2), 2019 - 150 Desyarti Safarini TLS ${ }^{*}$, Faqih Al Adyan ${ }^{2}$}

Berdasarkan hasil wawancara terhadap subjek penelitian, juga diketahui bahwa media software Geogebra dapat membantu siswa untuk melakukan visualisasi gambar lingkaran, memahami konsep dan menemukan formula, serta menghitung nilai akar suatu bilangan. Hal ini sesuai dengan kutipan wawancara dengan dua orang SP sebagai berikut:

A2 : "Ya jadi lebih semangat nyelesaiin soal-soal tugas, karena lebih gampang dipahamin jawabannya dan gak susah jalanin softwarenya."

T1 : "Iya kebantu soalnya jadi lebih gampang ngertiin gambar sama jawabannya. Saya malah lebih ngerti kalo langsung pakai programnya, bener deh! “

Dengan demikian dapat disimpulkan bahwa penerapan media software Geogebra telah membantu siswa mengatasi kesulitan belajar pada topik lingkaran. Hal ini sesuai dengan pernyataan NCTM (2000) bahwa teknologi seperti komputer dan kalkulator merupakan alat pokok untuk pembelajaran matematika yang berperan dalam penyediaan penggambaran atau visualisasi konsep-konsep matematika, membantu pengolahan data, serta melakukan perhitungan secara tepat dan akurat.

Lebih lanjut, penerapan media software Geogebra juga diintegrasikan dengan kegiatan diskusi kelompok dengan tujuan untuk membantu siswa dalam melakukan eksplorasi soal- soal baik dengan menggunakan media maupun secara analitik. Berdasarkan hasil wawancara terhadap seluruh subjek penelitian, diketahui bahwa siswa dalam mengerjakan soal latihan dan tugas kelompoknya sering berdiskusi dan meminta penjelasan dari teman sekelompoknya yang sudah menyelesaikan soal tersebut. Seluruh SP setuju bahwa diskusi kelompok membantu mereka dalam memahami materi, menyelesaikan soal latihan, dan tugas kelompok. Hal ini sesuai dengan kutipan wawancara dengan salah satu SP, yaitu sebagai berikut:

A1 : "Lebih suka belajar kelompok biar bisa sharing jawaban."

Berdasarkan paparan di atas, penerapan media software Geogebra yang diintegrasikan dengan diskusi kelompok telah berhasil meningkatkan hasil belajar siswa serta membantu siswa dalam belajar topik lingkaran. Media tersebut dapat membantu guru untuk menjelaskan konsep dasar kepada siswa serta meningkatkan efektifitas pengajaran. Selain itu, diskusi kelompok juga dapat meningkatkan interaksi positif antarsiswa. Kedua hal tersebut dapat mendukung tercapainya tujuan pembelajaran yang diharapkan. 


\section{Histogram: Jurnal Pendidikan Matematika, 3 (2), 2019 - 151 \\ Desyarti Safarini TLS ${ }^{*}$, Faqih Al Adyan ${ }^{2}$}

\section{KESIMPULAN DAN SARAN}

Berdasarkan paparan pada bagian hasil dan pembahasan, penerapan media software Geogebra dalam pembelajaran topik lingkaran dapat meningkatkan hasil belajar siswa. Hal ini dapat dilihat dari peningkatan hasil belajar siswa sebesar 30\%. Penerapan media software Geogebra pada pembelajaran di kelas dapat membantu siswa dalam memahami konsep dan melakukan visualisasi terhadap materi yang diajarkan oleh guru. Oleh karenanya siswa terbantu dalam mengatasi kesulitannya dalam memahami materi pada topik lingkaran, sehingga hasil belajarnya dapat meningkat. Lebih lanjut, penerapan media software Geogebra dalam pembelajaran juga diintegrasikan dengan kegiatan diskusi kelompok, sehingga siswa dapat saling berdiskusi dalam melaukan eksplorasi dan terbantu dalam menyelesaikan soal-soal baik pada latihan dan tugas kelompok. Penelitian ini dapat dikembangkan untuk mengetahui pengaruh positif dari penerapan media software Geogebra pada pembelajaran matematika terhadap hasil belajar siswa atau aspek lainnya, seperti motivasi, minat, atau persepsi siswa.

\section{DAFTAR PUSTAKA}

Dokovic, L. (2009). Applications GeoGebra into Teaching Some Topics of Mathematics at the College Level. Business Technical College: Siberia. Jurnal ComSIS Vol. 6 No. 2, December.

Freiman, V., Martinovic, D., \& Karadag, Z. (2010). A Snapshot of Geogebra Community Endeavors: Building A Research Agenda. Diunduh pada 15 Mei 2012 dari geogebraithaca.wikispaces.com/file/view/z10_os1-4-1.pdf

Machin, M. C., \& Rivero, R. D. (2002). Students' attitudes towards Mathematics and computers when using DERIVE in the learning of calculus concepts. The International Journal for Technology in Mathematics Education, 9(4), 259.Miles, M. B. and Huberman, M. A. (1994). Qualitative Analysis: An Expanded Sourcebook. Thousand Oaks, CA: Sage.

National Council of Teacher of Mathematics. (2000). Principles and Standards for School Mathematics. Reston: NCTM. Inc.

Reys, R., Lindquist, M, M., Lambdin, D, V., \& Smith, N, L. (2009). Helping Children Learn Mathematics. USA: John Wiley \& Sons, Inc.

Sugiyono, 2013, Metodelogi Penelitian Kuantitatif, Kualitatif Dan R\&D. Bandung: Alfabeta

Way, J., \& Beardon, T. (2003). ICT and Primary Mathematics. Philadelphia: Open University Press.

Widdiharto, R., Anggraeni, G., \& Guntoro, S. T. (2008). Paket Fasilitasi Pemberdayaan KKG/MGMP Matematika: Diagnosis Kesulitan Belajar Matematika SMP dan Alternatif Proses Remidinya. Yogyakarta: Pusat Pengembangan dan Pemberdayaan Pendidik dan Tenaga Kependidikan Matematika. 